\title{
Electroluminescence of Aluminium-Oxides' Nanoparticles in Overstressed Nanosecond Discharge Plasma in High-Pressure Air
}

\author{
O. K. Shuaibov, O. Y. Minya, A. O. Malinina, O. M. Malinin, \\ and I. V. Shevera
}

\author{
Uzhhorod National University, \\ 54, Voloshyn Str., \\ UA-88000 Uzhhorod, Ukraine
}

The results of the study of the electroluminescence of aluminium-oxide nanoparticles in plasma of an overstressed bipolar nanosecond discharge ignited between aluminium electrodes at an interelectrode distance of 2 $\mathrm{mm}$ and under an air pressure in the range of 50-202 $\mathrm{kPa}$ are presented. Aluminium vapour was introduced into the plasma due to microexplosions of inhomogeneities on the surface of the electrodes in a strong electric field $(E)$. The plasma of the discharge under study is characterized by a wide luminescence band in the spectral range of 300-430 nm, against the background of which, spectral lines of aluminium atoms and ions as well as nitrogen atoms and ions are observed. When air was replaced by argon of the same pressure and under the same ignition conditions of the discharge, these luminescence bands were absent. Based on the well-known published data on photo- and cathodoluminescence of solid-state alumina nanostructures, the broad luminescence bands from plasma were detected and attributed to the emission of the $F$ and $F^{+}$centres formed by oxygen vacancies in aluminium-oxide nanoparticles. The transmission spectra of thin films synthesized on glass substrates from plasma products were studied. Based on the BOLSIG+ program, the basic parameters of air plasma with a small admixture of aluminium vapour were simulated for the values of the $E / N$ parameters (the ratio of the electric field $(E)$ to the total concentration of the mixture of aluminium and air vapours $(N)$ ), which were realized in the experiment.

Представлено результати дослідження електролюмінесценції наночастинок оксиду алюмінію в плазмі надмірно напруженого біполярного наносекундного розряду, що запалюється між алюмінійовими електродами на міжелектродній віддалі у 2 мм і за тиску повітря в діяпазоні 50-202 кПа. Пари алюмінію потрапляли в плазму внаслідок мікровибухів неоднорідностей на поверхні електрод у сильному електричному 
полі $(E)$. Плазма досліджуваного розряду характеризується широкою смугою люмінесценції в спектральному діяпазоні 300-430 нм, на тлі якої спостерігаються спектральні лінії атомів і йонів Алюмінію, а також атоми та йони Нітрогену. Коли повітря замінювали аргоном з однаковим тиском і за однакових умов займання розряду, ці смуги люмінесценції відсутні. На основі відомих опублікованих даних про фото- та катодолюмінесценцію твердотільних наноструктур глинозему було виявлено широкі смуги люмінесценції з плазми, що пояснювалося емісією $F$ - і $F^{+}$-центрів, утворених вакансіями Оксиґену в наночастинках оксиду алюмінію. Вивчено спектри пропускання тонких плівок, синтезованих на скляних підкладинках із плазмових продуктів. На основі програми BOLSIG+ було змодельовано основні параметри повітряноі плазми з невеликою домішкою парів Алюмінію для значень параметрів $E / N$, яких було реалізовано в експерименті.

Key words: electroluminescence, nanostructures, aluminium, overstressed nanosecond discharge, argon, air.

Ключові слова: електролюмінесценція, наноструктури, алюміній, надмірно напружений наносекундний розряд, аргон, повітря.

(Received 23 March, 2020)

\section{INTRODUCTION}

The results of a study of the characteristics and kinetics of processes in heterogeneous plasma based on mixed flows of buffer gas argon, an oxidizing agent-water molecules and aluminium dust-are presented in Ref. [1]. In such plasma, the gas component, liquid droplets, solids and plasma simultaneously coexist. The work is related to the search for effective and cheap hydrogen production technologies based on the plasma-chemical oxidation of aluminium in water vapour. Because of such a stimulated process, aluminium dioxide is formed, and thermal energy is released [2]. Moreover, the value of obtaining a hydrogen molecule does not exceed 1.5 $\mathrm{eV} /$ molecule that is much more economical than in the hydrolysis method of producing hydrogen.

In Ref. [3], the characteristics and parameters of a high-current vacuum-arc discharge in aluminium vapour were studied, which were obtained by erosion of the electrodes at buffer gas pressures in the range of $1-10^{-3} \mathrm{~Pa}$. Aluminium plasma with an electron temperature of $1200-2200 \mathrm{eV}$ was obtained at an electron concentration of about $10^{17} \mathrm{~cm}^{-3}$.

When using a subnanosecond high-voltage discharge between aluminium electrodes, the results of studying the characteristics of aluminium atmospheric pressure plasma with the ectonic mechanism of aluminium vapour injection are presented in Ref. [4]. 
The use of aluminium plasma and oxygen-containing gases can be used for the synthesis of nanostructures of aluminium oxides, which in the form of thin films or powders can be used in the form of luminophores that stimulates the study of new physical methods of their synthesis $[5,6]$.

Currently, there are practically no works on the synthesis of alumina-based nanostructures using pulsed discharges with the ectonic mechanism [7] for the injection of aluminium vapour into oxygen-containing gas plasma. The results of such studies of the synthesis conditions and some characteristics of copper, zinc, and iron oxides' nanostructures are presented in Refs. [8-10].

This paper presents the results of a study of the synthesis conditions and the electroluminescence characteristics of aluminiumoxide nanostructures, which were synthesized in plasma of an overstressed nanosecond discharge between aluminium electrodes in air and argon.

\section{TECHNIQUE AND EXPERIMENTAL CONDITIONS}

An overstressed nanosecond discharge in air or argon was ignited in a 3-liter sealed dielectric chamber between aluminium electrodes. A diagram of a gas-discharge plasma-chemical reactor for the synthesis of nanostructured thin films of aluminium oxides is shown in Fig. 1. The diameter of the cylindrical aluminium electrodes was 5

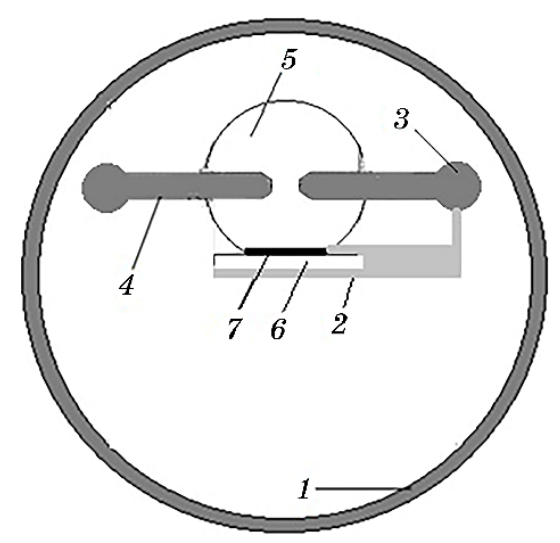

Fig. 1. The structure of the gas-discharge cell: 1 is the dielectric cell housing; 2 is the substrate fastening system for deposition of thin films; 3 is the electrode spacing adjustment system; 4 is the metal electrodes; 5 is the spatial deposition zone of the films; 6 is the glass substrate for films' deposition; 7 is a film based on the material of electrodes and fractions of air plasma. 
$\mathrm{mm}$. The radius of the rounded working end of the aluminium electrodes was of $3 \mathrm{~mm}$. The air and argon pressure varied in the range of $5.3-202 \mathrm{kPa}$. The distance between the electrodes was of $2 \mathrm{~mm}$. Aluminium vapour was introduced into the discharge gap due to microexplosions of the inhomogeneities of the surface of aluminium electrodes in a strong electric field of the discharge and the formation of ectons [7].

To ignite the discharge, high-voltage bipolar pulses with a total duration of 50-100 $\mathrm{ns}$ and amplitude of $\pm 20-40 \mathrm{kV}$ were applied to the electrodes.

The plasma volume depended on the repetition rate of voltage and current pulses and, in the frequency range of $10-150 \mathrm{~Hz}$, increased from 3 to $25 \mathrm{~mm}^{3}$. The discharge was photographed, using a digital camera, and as a scale, the distance between the electrodes was used to determine the plasma volume. With an interelectrode distance of 1-2 $\mathrm{mm}$, the discharge gap was highly overstressed. The nanosecond discharge at a pressure of $p=5-202 \mathrm{kPa}$ was quite uniform that was caused by the action of the preliminary ionization system, which, in this case, can be played by a runaway electron beam and the accompanying $\mathrm{x}$-ray radiation [11].

The voltage pulses at the discharge gap and the discharge current were measured, using a wide-band capacitive divider, a Rogowski coil, and a 6-LOR 04 wide-band oscilloscope. The temporal resolution of this recording system was of 2-3 ns. The spatial characteristics of the discharge were studied, using a digital camera. The pulse repetition rate varied in the range $f=35-1000 \mathrm{~Hz}$. The plasma radiation spectra were recorded, using an MDR-2 monochromator, a FEU-106 photomultiplier, a direct current amplifier, and an electronic potentiometer. The radiation of the discharge plasma was analyzed in the spectral range of 200-650 $\mathrm{nm}$. The plasma-radiation registration system was calibrated by the radiation of a deuterium lamp in the spectral range of $200-400 \mathrm{~nm}$ and a gang lamp in the range of $400-650 \mathrm{~nm}$. The pulsed electric power of an overstressed nanosecond discharge was determined by graphically multiplying the waveforms of voltage and current pulses. The time integration of the pulsed power made it possible to obtain energy in one electric pulse, which was introduced into the plasma.

Nanostructured thin films based on the degradation products of aluminium electrodes and air molecules were deposited during 2-3 hours of operation of the reactor in the form of a transparent thin film on glass or quartz substrates, which were installed at a distance of $3 \mathrm{~cm}$ from the centre of the discharge gap. The resulting films were studied for light transmission in the visible wavelength range. The experimental technique and technique for recording the transmission spectra of synthesized films are described in Refs. $[12,13]$. 


\section{ELECTRICAL AND OPTICAL CHARACTERISTICS}

Figure 2 presents an oscillogram of a voltage pulse between the aluminium electrodes at an air pressure of $101 \mathrm{kPa}$. Due to the mismatch of the output resistance of the pulse voltage generator and the plasma resistance, the voltage pulse took the form of short oscillations decaying in time, as in Ref. [4] for such a discharge of subnanosecond duration. The maximum range of the components of the voltage pulse of positive and negative polarities is in the range of $15-25 \mathrm{kV}$, and the duration of an individual spike was in the range of 5-10 ns. The shape of the current pulse repeated the shape of the voltage pulse. The maximum amplitudes of the positive and negative components of the current pulse reached 130-150 A.

The characteristic form of the pulsed electric power of an overstressed discharge between aluminium electrodes and the energy input in one pulse at an air pressure of $101 \mathrm{kPa}$ are shown in Fig. 3. The maximum pulsed-discharge power in air at a pressure of $50 \mathrm{kPa}$ reached $3 \mathrm{MW}$, and at a pressure of $101 \mathrm{kPa}$, it increased to 6.5 MW. With an increase in air pressure from 50 to $101 \mathrm{kPa}$, the en-

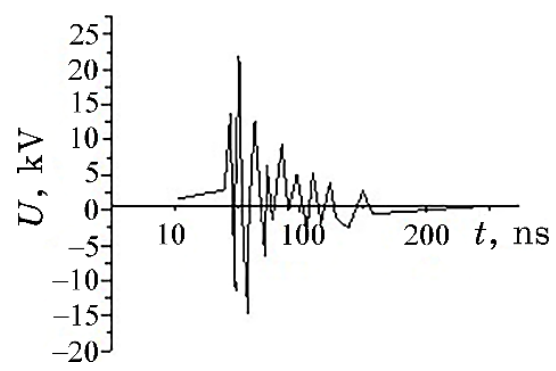

Fig. 2. Oscillograms of the voltage pulse of an overstressed nanosecond discharge between aluminium electrodes at an air pressure of $101 \mathrm{kPa}$.

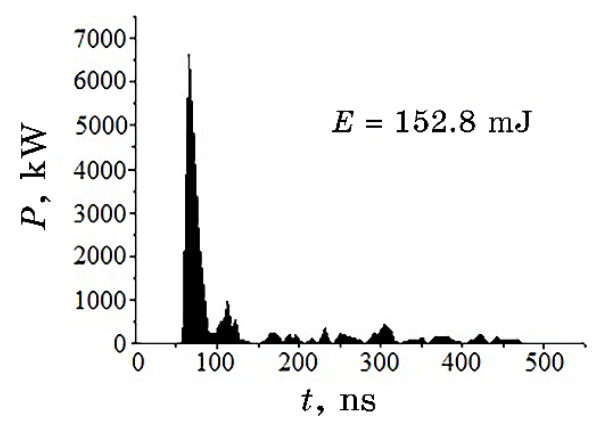

Fig. 3. Pulse power and energy input per pulse in a plasma at an air pressure of $101 \mathrm{kPa}$. 
ergy contribution to the plasma increased from $109.6 \mathrm{~mJ}$ to 152.8 mJ.

In Figures 4 and 5, the characteristic emission spectra of overstressed nanosecond discharge plasma between aluminium electrodes in air and argon are shown, respectively. The experiments with argon, which were carried out in the same pressure range as with air, were performed to demonstrate the absence of emission bands of nanostructures of aluminium oxides in an inert-gas plasma (in the absence of oxygen molecules). The spectra shown in Figs. 3 and 4 are registered under the same conditions for the excitation of the

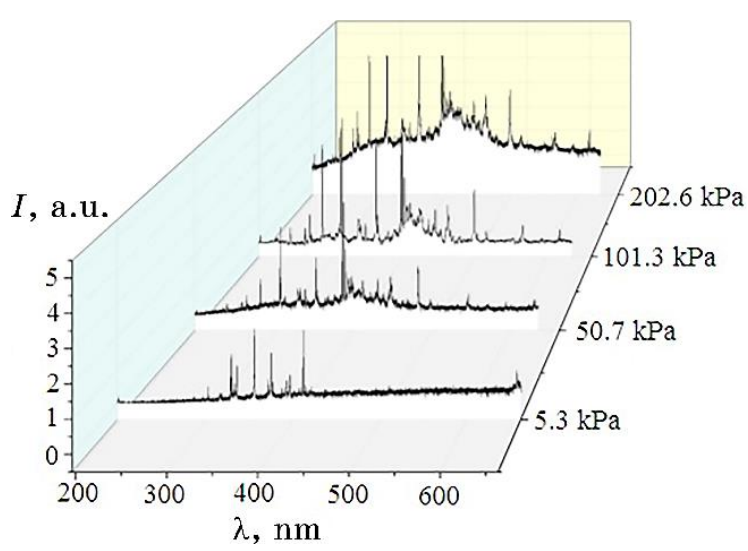

Fig. 4. Emission plasma spectra of an overstressed nanosecond discharge at different air pressures (of 5.3, 50.7, 101.3 and $202.6 \mathrm{kPa}$ ).

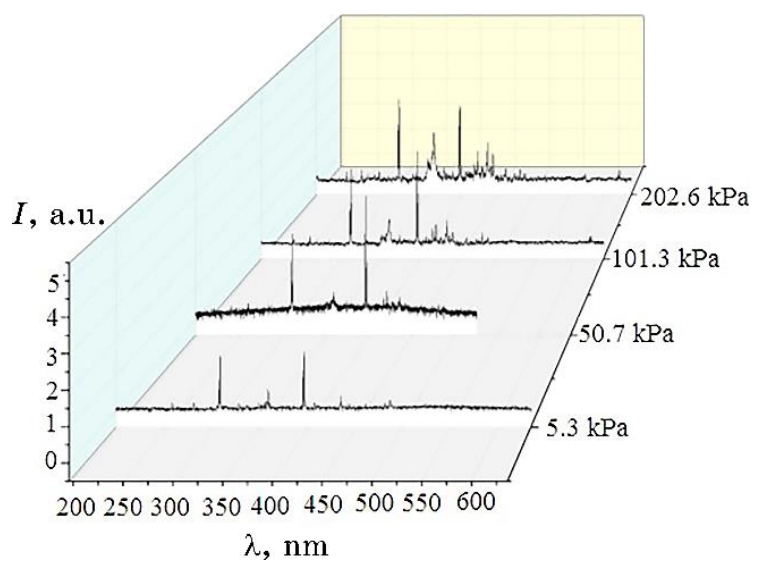

Fig. 5. Emission plasma spectra of an overstressed nanosecond discharge at different argon pressures (of 5.3, 50.7, 101.3 and $202.6 \mathrm{kPa}$ ). 
discharge and under the same conditions of registration. Therefore, the intensities of individual spectral lines and bands can be compared with each other.

It can be seen from these spectra that the intensity of the glow of the discharge plasma in air at all the pressures studied by us exceeds the radiation intensity of spectral lines and discharge bands in argon. In the emission spectra of air plasma with a small admixture of aluminium vapour, radiation was detected at the transitions of atom and singly charged aluminium ion, nitric oxide radicals and nitrogen molecules, as in the emission spectra of a subnanosecond plasma in a similar medium [4]. In an argon-based discharge, radiation was predominantly recorded at transitions of an atom and an aluminium ion.

In a discharge in air mixtures with a small admixture of aluminium vapour in the emission spectra (Fig. 4), broad emission bands with maxima in the spectral ranges of $410-420 \mathrm{~nm}$ and 300-390 $\mathrm{nm}$ are recorded. The highest radiation intensity of these bands was obtained at a maximum air pressure of $202 \mathrm{kPa}$. In argon-based mixtures, these bands are absent in the discharge emission spectra. It was noted in Ref. [5] that a wide emission band was observed with a maximum at a wavelength of $415 \mathrm{~nm}$ in the photoluminescence spectrum of anion-defective single crystals of nanostructured ceramics based on alumina, when the corresponding samples were excited by radiation with a wavelength of $205 \mathrm{~nm}$. This band coincides with that obtained in the present experiment. It is interpreted as the luminescence band of $F$ centres (the transition is $1 s-3 p$ with the maximum of the emission spectrum at an energy of $3.0 \mathrm{eV}$ and a decay time constant of $36-40 \mathrm{~ms}$ ) [5,6]. The results of studies of the cathodoluminescence spectra of nanostructured oxide ceramics were also presented in Ref. [5], which were close to the spectrum of aluminium. Cathodoluminescence was excited by a pulsed electron beam with a density of $1 \mathrm{~A} \cdot \mathrm{cm}^{-2}$, an energy of $180 \mathrm{keV}$, and a duration of $3 \mathrm{~ns}$. The spectrum of this cathodoluminescence was similar to the spectrum recorded in our experiment at an air pressure of $202 \mathrm{kPa}$. The main was the emission band with a maximum at wavelengths of 410-420 nm (quantum energy of $3.0 \mathrm{eV}$ ), which was adjoined by a wider short-wave band with quantum energy maxima at 3.4, 3.8, $4.3 \mathrm{eV}$ [5]. The ultraviolet bands photo- and cathodoluminescence bands of nanostructured alumina ceramics are associated with the emission of $F^{+}$centres created by oxygen vacancies and have a relatively short decay time (of 0.6-1.0 $\mu \mathrm{s}$ ) [5, 6].

Figure 6 presents the transmission spectrum of a film based on aluminium-oxide nanostructures synthesized at room temperature on a glass substrate in the visible region of the spectrum.

As can be seen from Fig. 6, the obtained film is characterized by 


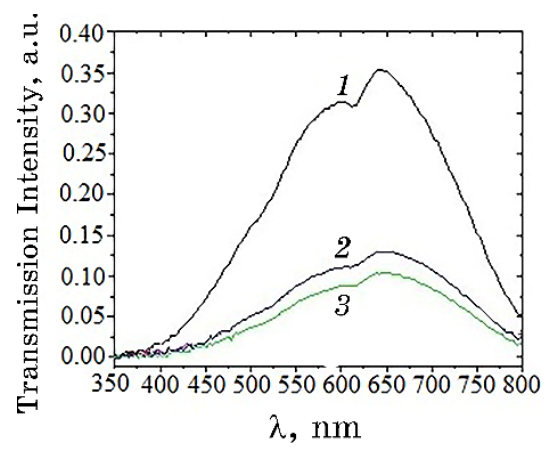

Fig. 6. The transmission spectra of a nanostructured alumina film on a glass substrate in the spectral region of $350-800 \mathrm{~nm}$ (band lamp): 1 is pure glass; 2 is a film obtained by sputtering aluminium electrodes in air at a pressure of $101 \mathrm{kPa}$, a current pulse repetition rate of $40 \mathrm{~Hz}$ and a sputtering time of 3 hours; 3 is a film synthesized by replacing aluminium electrodes with chalcopyrite-type $\mathrm{CuInSe}_{2}$ electrodes synthesized under the same conditions as a film 2 .

a weak transmission of radiation in the visible wavelength region, comparable with the transmission of radiation by a chalcopyrite film (which is such as a result of strong light absorption by chalcopyrite [14]). As is known, chalcopyrite films are used in photovoltaic devices (solar cells) and are effective converters of light into electricity [15]. According to Ref. [6], films based on nanostructured alumina ceramics are practically not transparent to the visible region of the spectrum; their transmission begins to increase in the spectral range of $0.8-2.0 \mu \mathrm{m}$ from $1-3$ to $25 \%$.

\section{PLASMA PARAMETERS}

The parameters of the discharge plasma for a mixture of aluminium and air vapours at atmospheric pressure (component ratio is $30 \mathrm{~Pa}: 202 \mathrm{kPa}$, respectively) were determined numerically and calculated as the total integrals of the electron-energy distribution function (EEDF) in the discharge. EEDFs were found numerically by solving the Boltzmann kinetic equation in the two-term approximation [16]. EEDF calculations were performed, using the program [9]. Based on the EEDFs obtained, mean electron energy, electron mobility, electron temperature, specific losses of electric-discharge power on inelastic and elastic processes of electron scattering by aluminium, argon, nitrogen, oxygen and carbon dioxide molecules, the ratio of which is $30: 60.6: 157741.8: 42319: 1878.6[\mathrm{~Pa}]$, depending on the magnitude of the reduced electric field (the ratio of the electric field $(E)$ to the total concentration of the mixture of alu- 
minium and air vapours $(N)$ ). The range of changes in the parameter $E / N=1-200$ Td $\left(1 \cdot 10^{-17}-2 \cdot 10^{-15} \mathrm{~V} \cdot \mathrm{cm}^{2}\right)$ included the values of the parameter $E / N$, which were realized in the experiment.

The following processes are taken into account in the integral of collisions of electrons with atoms and molecules: elastic scattering of electrons by aluminium atoms, excitation of energy levels of aluminium atoms (threshold energies of $3.1707 \mathrm{eV}, 2.9032 \mathrm{eV}$, $4.1463 \mathrm{eV}, 4.2339 \mathrm{eV}, 4.1296 \mathrm{eV}, 5.1220 \mathrm{eV}$ ), aluminium atom ionization (threshold energy of $6.0000 \mathrm{eV}$ ); elastic electron scattering by argon atoms, excitation of the energy level of argon atoms

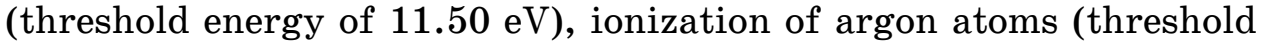
energy of $15.80 \mathrm{eV}$ ); elastic scattering and excitation of energy levels of nitrogen molecules: for rotational levels, threshold energy of $0.020 \mathrm{eV}$, for vibrational ones, threshold energies of $0.290 \mathrm{eV}$, $0.291 \mathrm{eV}, 0.590 \mathrm{eV}, 0.880 \mathrm{eV}, 1.170 \mathrm{eV}, 1.470 \mathrm{eV}, 1.760 \mathrm{eV}, 2.060$ $\mathrm{eV}, 2.350 \mathrm{eV}$, for electronic ones, threshold energies of $6.170 \mathrm{eV}$, $7.000 \mathrm{eV}, 7.350 \mathrm{eV}, 7.360 \mathrm{eV}, 7.800 \mathrm{eV}, 8.160 \mathrm{eV}, 8.400 \mathrm{eV}, 8.550$ $\mathrm{eV}, 8.890 \mathrm{eV}, 11.03 \mathrm{eV}, 11.87 \mathrm{eV}, 12.25 \mathrm{eV}, 13.00 \mathrm{eV}$, ionization (threshold energy of $15.60 \mathrm{eV}$ ); elastic scattering and excitation of energy levels of oxygen molecules: vibrational (threshold energies of $0.190 \mathrm{eV}, 0.380 \mathrm{eV}, 0.570 \mathrm{eV}, 0.750 \mathrm{eV}$ ), electronic (threshold energies of $0.977 \mathrm{eV}, 1.627 \mathrm{eV}, 4.500 \mathrm{eV}, 6.000 \mathrm{eV}, 8.400 \mathrm{eV}, 9.970$ $\mathrm{eV}$, dissociative electron attachment (threshold energy of $4.40 \mathrm{eV}$ ), ionization (threshold energy of $12.06 \mathrm{eV}$ ); elastic scattering and excitation of energy levels of carbon-dioxide molecules: vibrational (threshold energies of $0.083 \mathrm{eV}, 0.167 \mathrm{eV}, 0.252 \mathrm{eV}, 0.291 \mathrm{eV}$, $0.339 \mathrm{eV}, 0.422 \mathrm{eV}, 0.505 \mathrm{eV}, 2.5 \mathrm{eV}$ ), electronic (threshold energies of $7.0 \mathrm{eV}, 10.5 \mathrm{eV}$ ), dissociative electron attachment (threshold energy of $3.85 \mathrm{eV}$ ), ionization (threshold energy of $13.30 \mathrm{eV}$ ). Data on the absolute values of the effective cross sections of these processes, as well as their dependences on electron energies, were taken from the databases in [17-20].

The electron temperature in the gas-discharge plasma of the emitter was determined from the well-known formula [10]: $\varepsilon=3 k T / 2$, where $\varepsilon$ is the electron energy, $k$ is the Boltzmann constant, $T$ is a temperature in kelvins.

The electron drift velocity was determined from the expression [10]: $V_{d r}=\mu_{e} E$, where $\mu_{e}$-electron mobility, $E$-plasma field strength.

Plasma field strength $E$ was calculated by the formula: $E=U_{p l .} / d$, where $U_{p l}$ - voltage on plasma, $d$-discharge gap.

Electron concentration $\left(N_{e}\right)$ was determined by the well-known formula [10]: $N_{e}=j /\left(e V_{d r}\right)$, where $j$-discharge current density, $e-$ electron charge, $V_{d r}$.-electron drift velocity.

Mean energy of the discharge electrons almost linearly increases 

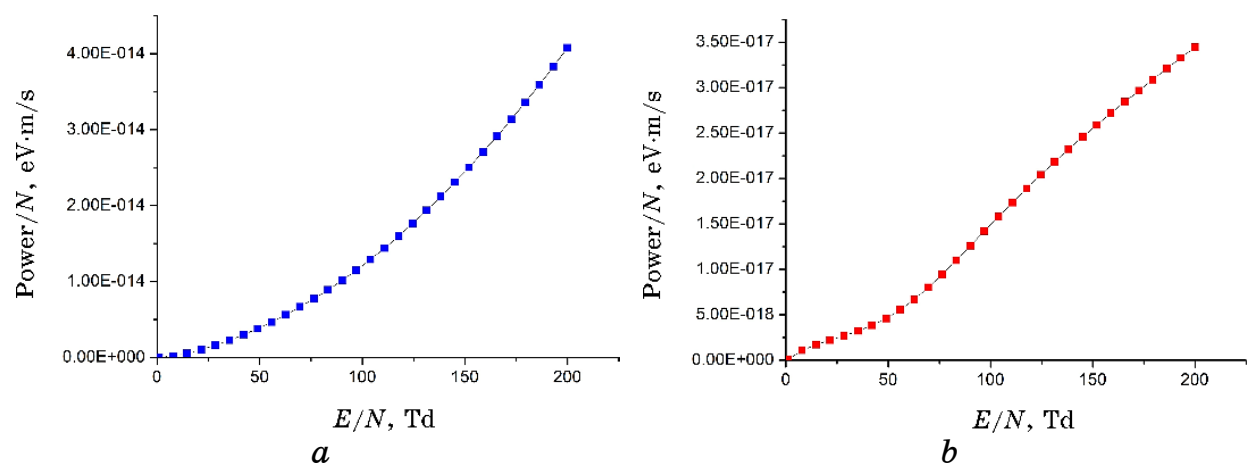

Fig. 7. Specific discharge power losses in the processes of inelastic $(a)$ and elastic (b) collisions of electrons with mixture components in gas-discharge plasma on the reduced electric field.

from $0.1432 \mathrm{eV}$ to $5.316 \mathrm{eV}$ with an increase in the $E / N$ parameter from $1 \mathrm{Td}$ to $200 \mathrm{Td}$. For the reduced electric field strength values of $51 \mathrm{Td}$ and $102 \mathrm{Td}$, at which experimental studies of the electrical and optical characteristics of the discharge were carried out, mean electron energies were $1.222 \mathrm{eV}$ and $2.860 \mathrm{eV}$, respectively, and their highest energies reached $20.84 \mathrm{eV}$ and $39.20 \mathrm{eV}$, respectively. The electron temperature in this case was of $14175.2 \mathrm{~K}$ and 33176 $\mathrm{K}$, and the electron drift velocities were of $8 \cdot 10^{4} \mathrm{~m} / \mathrm{s}$ and $1.122 \cdot 10^{6}$ $\mathrm{m} / \mathrm{s}$ at the values of the $E / N$ parameter of $51 \mathrm{Td}$ and $102 \mathrm{Td}$, respectively. The electron concentration at these parameters was of $3.9 \cdot 10^{21} \mathrm{~m}^{-3}$ and $5.7 \cdot 10^{20} \mathrm{~m}^{-3}$ at a current density of $5.1 \cdot 10^{6} \mathrm{~A} / \mathrm{m}^{2}$ and $1.02 \cdot 10^{7} \mathrm{~A} / \mathrm{m}^{2}$ on the surface of the electrode of the radiation source $\left(0.196 \cdot 10^{-4} \mathrm{~m}^{2}\right)$.

In Figure 7, $a, b$, the dependence of the specific power of the discharge losses in inelastic $(a)$ and elastic $(b)$ collisions of electrons with the components of the mixture in a gas-discharge plasma on the reduced electric-field strength is shown. An increase in power is observed with increasing values of the reduced electric field, both for inelastic processes and for elastic ones. The specific powers for the reduced electric-field strengths, at which our experiments were carried out, they were equal to: $0.3801 \cdot 10^{-14} \mathrm{eV} \cdot \mathrm{m}^{3} / \mathrm{s}$ and $0.1289 \cdot 10^{-13} \mathrm{eV} \cdot \mathrm{m}^{3} / \mathrm{s}$ for the reduced electric field of $51 \mathrm{Td}$, and $0.459710^{17} \mathrm{eV} \cdot \mathrm{m}^{3} / \mathrm{s}$ and $0.1579 \cdot 10^{-16} \mathrm{eV} \cdot \mathrm{m}^{3} / \mathrm{s}$ for a reduced electric field of $102 \mathrm{Td}$.

\section{CONCLUSION}

Thus, it was found that the plasma of an overstressed nanosecond discharge formed under the action of a packet of 5-10 ns voltage 
pulses with a total duration of 100-120 ns, between aluminium electrodes at air pressures of 50-202 $\mathrm{kPa}$, pulse discharge power of 3-6.5 MW and the energy input per pulse of $110-153 \mathrm{~mJ}$ is a source of luminescence of aluminium-oxide nanoparticles in the form of a wide band, which is in the spectral range of $300-430 \mathrm{~nm}$. The detected broad luminescence bands from nanosecond discharge plasma are assigned to the radiation of the $F$ - and $F^{+}$-centres of oxygen vacancies in nanostructured alumina ceramics. Upon deposition of degradation products of electrodes and air molecules in plasma on a glass substrate, films based on aluminium oxides were obtained, which are characterized by low transparency in the visible region of the spectrum.

The gas-discharge plasma, in which films based on aluminium oxides were obtained, had the following main parameters: mean energies, temperature, and electron concentration of $1.222 \mathrm{eV}$ and 2.860 $\mathrm{eV}, 14175.2 \mathrm{~K}$ and $33176 \mathrm{~K}, 3.9 \cdot 10^{21} \mathrm{~m}^{-3}$ and $5.7 \cdot 10^{20} \mathrm{~m}^{-3}$, respectively. The values of the reduced electric field were of $51 \mathrm{Td}$ and $102 \mathrm{Td}$. The specific discharge power for inelastic and elastic collisions of electrons with atoms and molecules, which were part of the working mixture of a gas-discharge plasma are increased by a unit of the total concentration of the mixture with an increase in the reduced electric field for both inelastic and elastic processes. For these values of the reduced electric field, at which the experimental studies were carried out, they were equal to $0.3801 \cdot 10^{-14} \mathrm{eV} \cdot \mathrm{m}^{3} / \mathrm{s}$ and $0.1289 \cdot 10^{-13} \mathrm{eV} \cdot \mathrm{m}^{3} / \mathrm{s}$, as well as $0.4597 \cdot 10^{-17} \mathrm{eV} \cdot \mathrm{m}^{3} / \mathrm{s}$ and $0.1579 \cdot 10^{-16} \mathrm{eV} \cdot \mathrm{m}^{3} / \mathrm{s}$, respectively.

\section{REFERENCES}

1. V. A. Bityurin, A. V. Grigorenko, A. V. Efimov, A. I. Klimov, O. V. Korshunov, D. S. Kutuzov, and V. F. Chinnov, High Temperature, 52: 3 (2014); https://doi.org/10.7868/S0040364414010050

2. E. I. Shkolnikov, A. Z. Beetle, B. M. Bulychev, M. N. Larichev, A. V. Ilyukhina, and M. S. Vlaskin, Oxidation of Aluminum with Water for Efficient Power Generation (Moscow: Science, Joint Institute for High Temperatures, RAS: 2012).

3. M. A. Krasnogolovets, Technical Physics, 44: 1388 (1999); https://doi.org/10.1134/1.1259531

4. D. V. Beloplotov, V. F. Tarasenko, and M. I. Lomaev, Optika Atmosfery $i$ Okeana, 29, No. 2: 96 (2016) (in Russian).

5. V. S. Kortov, A. E. Ermakov, A. F. Zatsepin, M. A. White, S. V. Nikiforov et al., Solid State Physics, 50: 916 (2008); https://doi.org/10.1134/S1063783408050259

6. I. V. Gasenkova, N. I. Mukhurov, and Yasin Mohsin Vakhioh, Reports of BSUIR, 96: 114 (2016).

7. G. A. Mesyats, Usp. Fizich. Nauk, 165: 601 (1995) (in Russian); 
https://doi.org/10.3367/UFNr.0165.199506a0601

8. A. K. Shuaibov, A. Y. Minya, A. A. Malinina, A. N. Malinin, V. V. Danilo, M. Yu. Sichka, and I. V. Shevera, American Journal of Mechanical and Ma terials Engineering, 2: 8 (2018); https://doi.org/10.11648/j.ajmme.2018.0201.12

9. A. K. Shuaibov, A. I. Minya, Z. T. Gomoki, V. V. Danilo, and P. V. Pinzenik, Surface Engineering and Applied Electrochemistry, 55: 65 (2019); https://doi.org/10.3103/S1068375519010137

10. O. K. Shuaibov, A. A. Malinina, and A. N. Malinin, New Gas-Discharge Methods for Producing Selective Ultraviolet and Visible Radiation and Synthesis of Transition Metal Oxide Nanostructures (Uzhhorod: Publishing house UzhNU 'Goverla': 2019).

11. V. F. Tarasenko, Runaway Electrons Preionized Diffuse Discharge (New York: Nova Science Publishers Inc.: 2014).

12. V. M. Holovey, K. P. Popovych, M. V. Prymak, M. M. Birov, V. M. Krasilinets, and V. I. Sidey, Physica B, 450: 34 (2014); https://doi.org/10.1016/j.physb.2014.05.059

13. A. K. Shuaibov, A. Y. Minya, Z. T. Gomoki, R. V. Hrytsak, A. A. Malinina, and A. N. Malinin, Journal of Physics and Chemistry Research, 1: 1 (2019).

14. Ya. Vertsimakha, P. Lutsuk, O. Lytvyn, and P. Gashin, Ukr. J. Phys., 52: 399 (2007).

15. G. F. Novikov and M. V. Gapanovich, Physics-Uspekhi, 187: 173 (2017); https://doi.org/10.3367/UFNr.2016.06.037827

16. G. J. M. Hagelaar and L. C. Pitchford, Plasma Sources Sci. Technol., 14: 722 (2005); https://doi.org/10.1088/0963-0252/14/4/011

17. http:/www.bolsig.laplace.univ-tlse.fr

18. L. L. Shimon, Scientific Bulletin of Uzhhorod University. Physics Series, 20: 55 (2007).

19. http://www.ioffe.ru/ES/Elastic/data2.html

20. https://physics.nist.gov/cgi-bin/Ionization/ion_data.php?id=AlI\&ision=I\&initial=\&total=Y 